\title{
Book Review: Municipal Infrastructure Financing: Innovative Practices from Developing Countries
}

\section{Commonwealth Journal of Local Governance \\ Issue 8/9: May-November 2011 \\ http://epress.lib.uts.edu.au/ojs/index.php/cjlg}

\author{
Kevin Tayler \\ Water and Sanitation Consultant, \\ Honorary Professor, Cardiff University
}

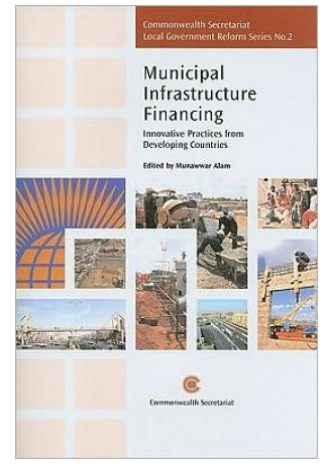

\section{BOOK REVIEW: Municipal Infrastructure Financing: Innovative Practices from Developing Countries}

Edited by Munawwar Alam (Commonwealth Secretariat, London, UK, 2010)

Rapid urbanisation creates a need to expand urban services and that expansion is not possible without adequate finances. However, fiscal decentralization has not kept pace with administrative and functional decentralisation so that municipal bodies lack the funds required to operate existing facilities and extend services into new areas. Municipal Infrastructure Financing addresses this issue. It draws on a desk-based secondary study of relevant literature and municipal data, supplemented by primary research in four case study municipalities: Dar es Salaam and Kampala in East Africa, and Karachi and Dhaka in South Asia. The first two chapters provide a general overview of the book and of the state of municipal finance in Commonwealth developing countries. Chapters $3-6$ set out the findings of the four case studies, Chapter 7 examines a number of innovative approaches to municipal financing and Chapter 8 draws conclusions from what has gone before.

Chapter 2 makes two key points: First, local governments generally have a limited and relatively inelastic tax base and are therefore reliant on transfers from higher levels of government; and Second, the high pace of institutional and political decentralisation in 
recent years has not been matched by fiscal decentralisation. The result is that local governments have more responsibilities than ever, but are still reliant on a limited and inflexible tax base and transfers from higher levels of government. It is worth pointing out here that local governments in South Asia have lost the one substantial source of tax revenue that they used to have, the octroi tax on the movement of goods.

The following chapters provide a good overview of the situation in the four case study cities. They confirm that all four rely on transfers from higher levels of government, most notably in Karachi, where own-source revenues constitute only about $14 \%$ of total income. Forecast figures were considerably better but experience elsewhere in Pakistan suggests that optimistic forecasting of own-source receipts is common, but rarely justified. Only Dhaka raises more than $50 \%$ of its revenue from its own sources. In all four cities, finance from municipal borrowing is negligible, in the case of Karachi at least because it is not allowed. The book briefly reviews in-country supply-side capacity to provide municipal loans and bonds, suggesting some variations from country to country. In some cases this is a constraint. In others, it seems that the main constraint is the creditworthiness of the municipalities themselves. Apart from the failed PSP initiative for water and sanitation in Dar es Salaam, engagement with the private sector has been mainly low-key management contracts, often for solid waste collection. It is worth noting that the four case study cities are the largest in their respective countries and, as such, are likely to have more capacity to implement financial innovations than smaller municipalities.

Chapter 7 is the core of the book, providing examples of innovative approaches to municipal infrastructure financing. These include national development banks and financial institutions, borrowing from capital markets through municipal bonds, specialised municipal intermediaries providing either funds, guarantees and insurances, and public private partnerships defined as risk-sharing relationships between the public and private sectors. It is perhaps not surprising that the example of a long-term bond issue is that of Johannesburg, a city with well developed institutions. All the examples of revenue bonds come from India's southern States, and again appear to illustrate the fact that a city must be fairly well managed and financially secure before it can consider such options. They also, crucially, assume that local government can borrow and it is worth noting that efforts to replicate the Tamil Nadu/Karnataka urban development fund model in Punjab, Pakistan were unsuccessful until the emphasis of the organisation was shifted 
from providing loans to managing grants from Central Government and providing technical assistance. Examples of specialised financial intermediaries come from a wider range of countries, including Vietnam, the Philippines, Brazil and Colombia.

The conclusions are drawn in Chapter 8. Some, for instance that devolution of fiscal powers has been limited to date, have emerged in previous chapters. Others, for instance that transfers from higher levels of government have been inadequate, are hardly surprising. Another conclusion that poor financial management contributes to weaknesses in municipal finances, is clearly very important. Indeed, the more general problem of weak municipal management systems and the resultant lack of municipal capacity is surely one reason, perhaps the main reason, why private and public sector funders are reluctant to lend to municipalities. Many of the 'fundamental' strengthening measures suggested towards the end of the Chapter, for instance establishing an enabling policy environment and an appropriate legal and regulatory regime, are well established. Others are clearly needed, but the real challenge is to determine how they might be brought about. The recommendation that municipalities should strive to balance their books through a combination of revenue enhancement and cost containment measures could have developed the point made at the beginning of the book that municipal revenues tend to be inelastic and so difficult to enhance.

The book is well written and the tables are clear and relevant. It is well referenced. Indeed, Chapter 9 is actually a detailed listing of primary and secondary sources of information. In summary, this book contains four useful case studies and introduces a number of interesting initiatives in the field of municipal finance. In doing this, it will perhaps provide a starting point for those who are interested in these initiatives to find out more about them and explore their relevance to their own situations. This would appear to be a more than adequate reason for reading it. 